\title{
Pentoxifylline prevents indomethacin induced acute gastric mucosal damage in rats: role of tumour necrosis factor alpha
}

\author{
L Santucci, S Fiorucci, M Giansanti, P M Brunori, F M Di Matteo, A Morelli
}

\begin{abstract}
Neutrophil adherence within the gastric microcirculation is thought to be a major step in the pathogenesis of gastric mucosal damage induced by indomethacin. Pentoxifylline, a methylxanthine derivative, prevents leukocyte adherence to vascular endothelium and protects organs from shock by reducing tumour necrosis factor $\alpha$ (TNF $\alpha)$ concentrations. Rats were treated with $20 \mathrm{mg} / \mathrm{kg}$ oral indomethacin, pretreated with vehicle or with four different doses of pentoxifylline intraperitoneally, and killed after three hours. The gross gastric mucosal injury, neutrophil margination into the gastric microcirculation, mucosal concentrations of 6-keto-prostaglandin $F_{1 \alpha}\left(P G F_{1 \alpha}\right)$, and PGE $P_{2}$ and serum TNF $\alpha$ values were measured. Whether the pentoxifylline induced protection involved nitric oxide mediated pathways or gastric acid secretion was evaluated. The data indicate that pentoxifylline reduces indomethacin induced mucosal damage and neutrophil margination in a dose dependent manner without exerting any effect on gastric mucosal prostaglandin concentrations. The maximally effective dose $(200 \mathrm{mg} / \mathrm{kg})$ of pentoxifylline reduced gastric damage by $90 \%$ and slightly stimulated acid secretion. The effect of pentoxifylline was not affected by pretreatment with the nitric oxide inhibitor. Pentoxifylline prevented the indomethacin induced increase in TNF $\alpha$ concentrations in a dose dependent fashion. Serum TNF $\alpha$ values were $30.5(7 \cdot 0)$ IU $/ \mathrm{ml}$ (mean (SEM)) in rats treated with indomethacin alone and $5.0(2.5) \mathrm{IU} / \mathrm{ml}(p<0.01)$ in rats treated with indomethacin plus $200 \mathrm{mg} / \mathrm{kg}$ pentoxifylline. Pentoxifylline, therefore, prevents the acute gastric mucosal damage and neutrophil margination induced by indomethacin and reduces indomethacin induced release of TNF $\alpha$. (Gut 1994; 35: 909-915)
\end{abstract}

Ulcerative lesions of the gastrointestinal tract are one of the major side effects associated with the use of non-steroidal anti-inflammatory drugs (NSAIDs). ${ }^{1}$ Although the mechanism of NSAID induced gastric injury is unclear, evidence is accumulating that neutrophils (PMNs) play a crucial role. ${ }^{2-5}$ Depletion of circulating PMNs by antineutrophil serum or methotrexate prevents NSAID induced gastric damage in rats, without interfering with prostaglandin metabolism. ${ }^{34}$ Moreover, it has been shown that prevention of PMN adherence to the endothelium by treatment with a serum specifically directed against the PMN adhesion complex (CD18) reduces the gastrointestinal injury induced by indomethacin and ischaemia-reperfusion. ${ }^{56}$

Pentoxifylline (PTX) is a methylxanthine derivative that exerts a number of haemorrheological, haemodynamic, and anti-inflammatory effects. PTX has recently been shown to reduce effectively $P M N$ adherence in vitro in septic shock and ischaemia-reperfusion models. ${ }^{7}$ Furthermore, PTX inhibits synthesis and release of the tumour necrosis factor $\alpha$ (TNF $\alpha)$ by macrophages. ${ }^{8-10}$ TNF $\alpha$ is a cytokine that is known to stimulate considerably the adherence of PMN to the vascular endothelium by inducing the expression of $\beta_{2}$ integrins (LFA-1 and MAC-1). ${ }^{11-13}$ Administration of $\mathrm{TNF} \alpha$ to rats leads to vasocongestion, leukocyte margination, and tissue damage, and this effect is particularly evident in the gastrointestinal tract. ${ }^{13-16}$ Furthermore, it has been shown that, both in vitro and in vivo, NSAIDs increase $\mathrm{TNF} \alpha$ concentrations by inhibiting $\mathrm{PGE}_{2}$ synthesis. ${ }^{17-20}$ However, the part TNF $\alpha$ plays in the pathogenesis of NSAID induced gastrointestinal damage is unknown.

The present study evaluated whether: (1) PTX reduces gastric mucosal damage induced by indomethacin; (2) PTX administration modulates gastric acid secretion, serum $\mathrm{TNF} \alpha$ values, and $P M N$ infiltration into the gastric microcirculation; and (3) a functioning prostaglandin or nitric oxide (NO) system, or both, is required for PTX to protect the gastric mucosa against indomethacin induced gastric injury.

\section{Methods}

ASSESSMENT OF GASTRIC DAMAGE

Male Wistar rats (200-250 g), obtained from Charles River, Italia (Como, Italy), were fasted for 20-22 hours and deprived of water two to four hours before each experiment. Gastric mucosal damage was induced by the intragastric instillation of $20 \mathrm{mg} / \mathrm{kg}$ indomethacin (Sigma, St Louis, MO, USA) dissolved in 5\% sodium bicarbonate. This dose of indomethacin has been found to elicit macroscopically visible haemorrhagic erosions and ulcers in the stomach of normal rats. ${ }^{3}$ The control group received only the vehicle $(5 \%$ 
sodium bicarbonate). Gastric damage was assessed three hours after administration of indomethacin. The rats were killed and the stomachs rapidly removed, opened by an incision along the greater curvature, pinned out on a wax platform, and photographed. The lesions, haemorrhagic or ulcerative, were counted and measured with microcalipers by an observer who was unaware of the treatment. ${ }^{3}$ The gastric damage score was then calculated as the sum of the lengths of all lesions. Samples $(3 \times 10 \mathrm{~mm})$ of the corpus were excised and transferred to fresh formalin for histological studies and later processed by routine techniques before embedding in paraffin. Sections $4 \mu \mathrm{m}$ thick were mounted on glass slides and stained with haematoxylin and eosin. Coded slides were examined by an experienced pathologist unaware of the treatment. The extent of leukocyte margination in the sections was scored on a $0-3$ scale, ${ }^{3}$ where 0 indicated none; 1 limited to superficial (subepithelial) vessels; 2 extending to the bottom of the gastric glands; 3 extending to the vessels immediately above the muscularis mucosae or submucosa, or both.

\section{PROSTAGLANDIN MEASUREMENT}

In the same set of experiments, samples of the body region of the stomach, including the whole gastric wall, were excised for determining 6-keto-prostaglandin $\mathrm{F}_{1 \alpha}$ (6-keto-PGF $\mathrm{PG}_{1 \alpha}$ ) and prostaglandin $\mathrm{E}_{2}\left(\mathrm{PGE}_{2}\right)$ concentrations. ${ }^{21}$ Briefly, the tissue samples were weighed and then homogenised on ice in 4.3 $\mathrm{ml}$ of Tris buffer plus $1 \mathrm{mM}$ EDTA ( $\mathrm{pH} 8.9$ at $5^{\circ} \mathrm{C}$ ) using a ground glass homogeniser. The homogenates were centrifuged at $2000 \mathrm{~g}$ for 10 minutes to remove the tiny amounts of solid tissue debris. The resultant supernatant was then acidified with acetic acid. Prostaglandins were extracted from the supernatant using columns packed with reverse-phase octadecylsilane bonded silica gel (Sep-Pac C18, Waters, Millipore Co, Milford, MT). Columns were conditioned before use by washing them with $5 \mathrm{ml}$ of ethanol, followed by $5 \mathrm{ml}$ water. The acidified supernatants were added to the column that was then washed sequentially with $5 \mathrm{ml}$ of $15 \%$ ethanol and $5 \mathrm{ml}$ of toluene. Prostaglandins were eluted with $2 \mathrm{ml}$ of ethyl acetate, the solvent evaporated under a stream of nitrogen gas and the prostaglandins assayed using a specific enzyme immunoassay (Cayman Chemical Co, Ann Arbor, MI). The lower detection limit of the prostaglandin assay was $7 \mathrm{pg} / \mathrm{ml}$, with a sensitivity of $90 \%$ and a specificity of $100 \% .^{22} 23$ Results are expressed as $\mathrm{pg} / \mathrm{mg}$ of wet tissue.

\section{EFFECT OF PTX ON BASAL GASTRIC ACID} SECRETION

To evaluate the effect PTX exerts on basal gastric acid secretion, three groups of five rats each were pretreated with vehicle, $200 \mathrm{mg} / \mathrm{kg}$ intraperitoneal PTX, or $15 \mathrm{mg} / \mathrm{kg}$ intraperitoneal ranitidine. One hour later, rats were killed by an overdose of ether, and laparotomy was performed. The stomach was clamped at the junctions with the oesophagus and duodenum and excised. The gastric contents were emptied into a glass tube, centrifuged at 1000 $\mathrm{rpm}$, the volume measured, and the amount of titrable acidity determined by titrating the samples at $\mathrm{pH} 7.0$ with $0.01 \mathrm{~mol} / 1 \mathrm{NaOH}$ using an automatic titration system (Radiometer, Copenhagen, Denmark).

\section{COLORIMETRIC ASSAYS FOR DETECTION OF} TNF $\alpha$ IN RAT SERUM

The chests of rats were opened and blood was drawn directly from the heart under anaesthesia. The biologically active $\mathrm{TNF} \alpha$ was determined by a previously described cytotoxicity assay. ${ }^{24}$ Briefly, mouse fibrosarcoma L929 cells, which are highly sensitive to $\mathrm{TNF} \alpha$, were used as target cells. Cells $\left(4 \times 10^{5}\right)$ were cultured in 96-well microtitre plates at $37^{\circ} \mathrm{C}$ in $100 \mu \mathrm{l} \mathrm{RPMI} 1640$ medium (Sigma, Milano, Italy) containing $10 \%$ fetal calf serum and $1 \mu \mathrm{g} / \mathrm{ml}$ actinomycin $\mathrm{D}$ (Boeheringer Manneheim Biochemicals, Milano, Italy). Samples of rat serum $(100 \mu \mathrm{l})$ were added to the wells and incubated with the L929 cells for 24 hours at $37^{\circ} \mathrm{C}$. Cytopathic effects induced by $\mathrm{TNF} \alpha$ were assessed by staining fibrosarcoma cells with a $0 \cdot 1 \%$ solution of crystal violet suspension in 5\% ethanol. One unit of $\mathrm{TNF} \alpha$ was defined as the concentration at which $50 \%$ of the L929 cells manifested cytopathic effects. Purified recombinant human TNF $\alpha$ (Boeheringer Manneheim Biochemicals, Milano, Italy) was included as standard in each assay. A dose/response curve of TNF $\alpha$ release was determined on the same rats as in Figure 1 after intraperitoneal administration of PTX at doses of 200, 100, 50 , and $20 \mathrm{mg} / \mathrm{kg}$ (Fig 7) 30 minutes before indomethacin.

\section{EFFECT OF PTX ON INDOMETHACIN INDUCED} GASTRIC DAMAGE

A dose/response curve of the effect that PTX (Trental, Hoechst, Milano, Italy) exerted on indomethacin induced gastric mucosal damage was constructed using five groups of rats treated as follows: group $\mathrm{A}, 20 \mathrm{mg} / \mathrm{kg}$ oral indomethacin alone; group B, $200 \mathrm{mg} / \mathrm{kg}$ intraperitoneal PTX given 30 minutes before the indomethacin; group C, $100 \mathrm{mg} / \mathrm{kg}$ intraperitoneal PTX given 30 minutes before indomethacin; group $\mathrm{D}, 50 \mathrm{mg} / \mathrm{kg}$ intraperitoneal PTX given 30 minutes before indomethacin; and group $\mathrm{E}, 20 \mathrm{mg} / \mathrm{kg}$ intraperitoneal PTX given 30 minutes before indomethacin.

EFFECT OF PRETREATMENT WITH INHIBITOR OF NO BIOSYNTHESIS ON PTX INDUCED PROTECTION

In a separate set of experiments, five groups of rats were assigned to receive one of the following treatments: group $\mathrm{A}, 20 \mathrm{mg} / \mathrm{kg}$ oral indomethacin; group B, $40 \mathrm{mg} / \mathrm{kg}$ of $\mathrm{N} \omega$-nitroL-arginine (L-NNA) ${ }^{25}$ (Sigma, Milano, Italy) 


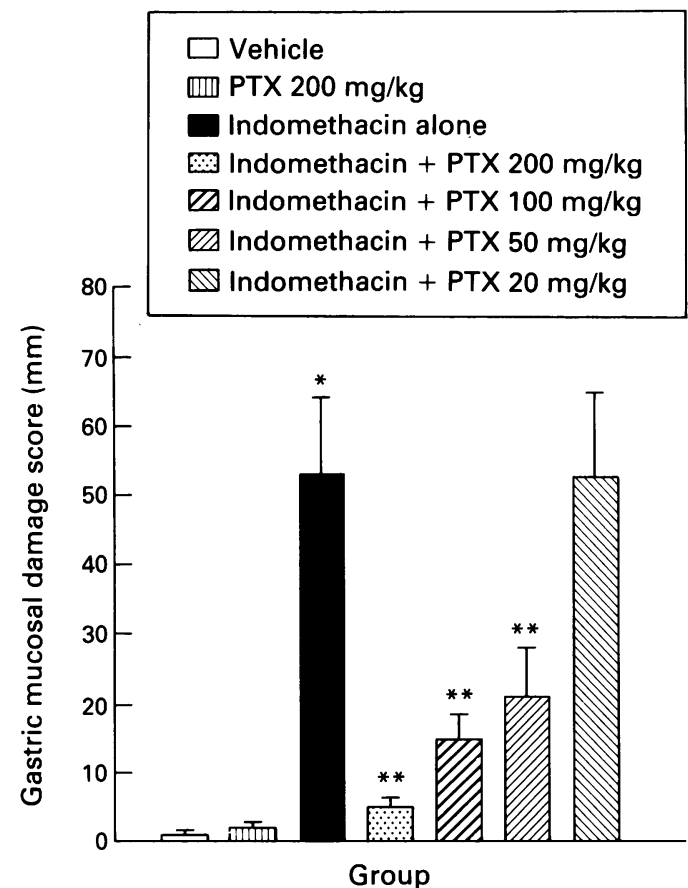

Figure 1: Effect of pentoxifylline (PTX) administration on the gastric mucosal damage score induced by intragastric instillation of $20 \mathrm{mg} / \mathrm{kg}$ indomethacin or vehicle $(5 \%$ sodium bicarbonate). Each group consisted of five to 10 rats. ${ }^{\star} p<0.01 \mathrm{v}$ vehicle; ${ }^{\star \star} p<0.01 \mathrm{v}$ indomethacin group (ANOVA and Student-Newman-Keul's test).

given intraperitoneally 30 minutes before vehicle; group C, $40 \mathrm{mg} / \mathrm{kg} \mathrm{L-NNA}$ given intraperitoneally 30 minutes before $20 \mathrm{mg} / \mathrm{kg}$ indomethacin; group D, $40 \mathrm{mg} / \mathrm{kg} \mathrm{L}-\mathrm{NNA}$ and $200 \mathrm{mg} / \mathrm{kg}$ PTX given intraperitoneally 30 minutes before $20 \mathrm{mg} / \mathrm{kg}$ indomethacin; and group E, $200 \mathrm{mg} / \mathrm{kg}$ intraperitoneal PTX given 30 minutes before $20 \mathrm{mg} / \mathrm{kg}$ indomethacin.

\section{STATISTICAL ANALYSIS}

All data are expressed as mean (SEM). Differences between groups were compared using an analysis of variance (ANOVA) followed by a Student-Newman-Keul's test. A probability ( $p$ value) of $<5 \%$ was considered significant.

\section{Results}

GASTRIC DAMAGE

Luminal administration of the vehicle produced negligible damage in the rat stomach, while indomethacin caused haemorrhagic and ulcerative lesions (Fig 1). The ulcerations were linear, with a mean length of 6-7 mm, and were frequently located along the rugal folds, while the antrum was largely spared. The mean gastric mucosal damage score was $52.4(11.0) \mathrm{mm}$ in indomethacin treated rats. PTX administration reduced indomethacin induced gastric damage in a dose dependent fashion. The maximum dose of PTX $(200 \mathrm{mg} / \mathrm{kg})$ reduced the extent of indomethacin induced damage by $90 \%(5 \cdot 0$ (1.2) mm; p<0.01) (Fig 1). PTX alone caused slight oedema and hyperaemia of gastric mucosa. When the percentage reduction of gastric damage induced by $20 \mathrm{mg} / \mathrm{kg}$ indomethacin was plotted against the PTX concentrations tested, a linear correlation was found (Fig 2). The $50 \%$ inhibitory dose $\left(\mathrm{ID}_{50}\right)$ was $50 \mathrm{mg} / \mathrm{kg}$.

PMN MARGINATION INTO GASTRIC MUCOSA Indomethacin resulted in extensive vascular engorgement of the mucosal and submucosal vessels. The results of the histological evaluation of PMN margination into the gastric microcirculation are shown in Figure 3 . Indomethacin induced a significant increase in PMN margination. PTX, in doses of 200 and $100 \mathrm{mg} / \mathrm{kg}$, significantly reduced the margination score ( $\mathrm{p}<0.05 v$ indomethacin alone). As shown previously for the gastric damage score,

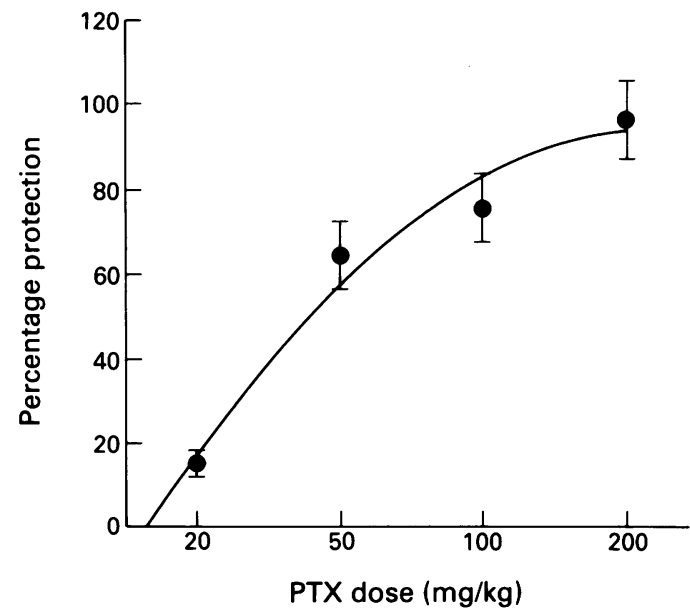

Figure 2: Correlation between the percentage reduction in gastric mucosal damage and pentoxifylline (PTX) doses. (Data were obtained from Figure 1.)

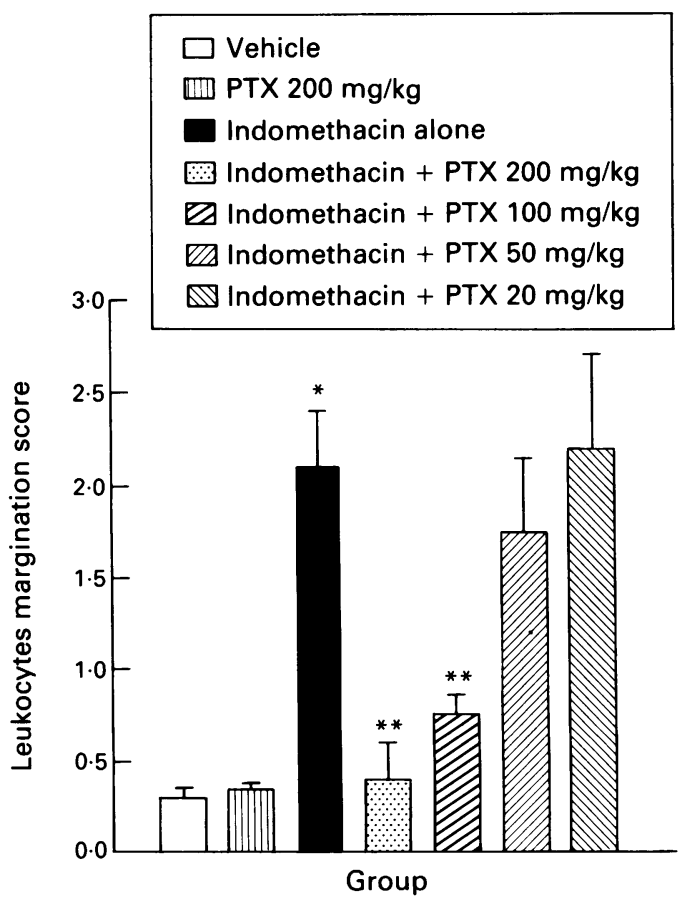

Figure 3: Effect of pentoxifylline (PTX) administration on the histological score of leukocyte margination induced by intragastric instillation of $20 \mathrm{mg} / \mathrm{kg}$ indomethacin or vehicle (5\% sodium bicarbonate). Each group consisted of five to 10 rats. ${ }^{\star} p<0.05 \mathrm{v}$ vehicle; ${ }^{\star \star} p<0.05 \mathrm{v}$ indomethacin alone group. (See Methods for details of the criteria used for scoring.) 


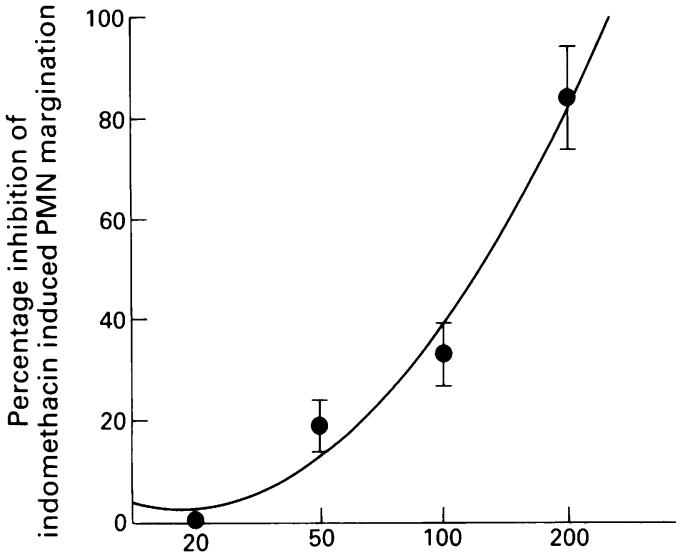

PTX dose $(\mathrm{mg} / \mathrm{kg})$

Figure 4: Correlation between the percentage reduction in the polymorphonuclear (PMN) infiltration score and pentoxifylline (PTX) doses. (Data were obtained from Figure 3.)
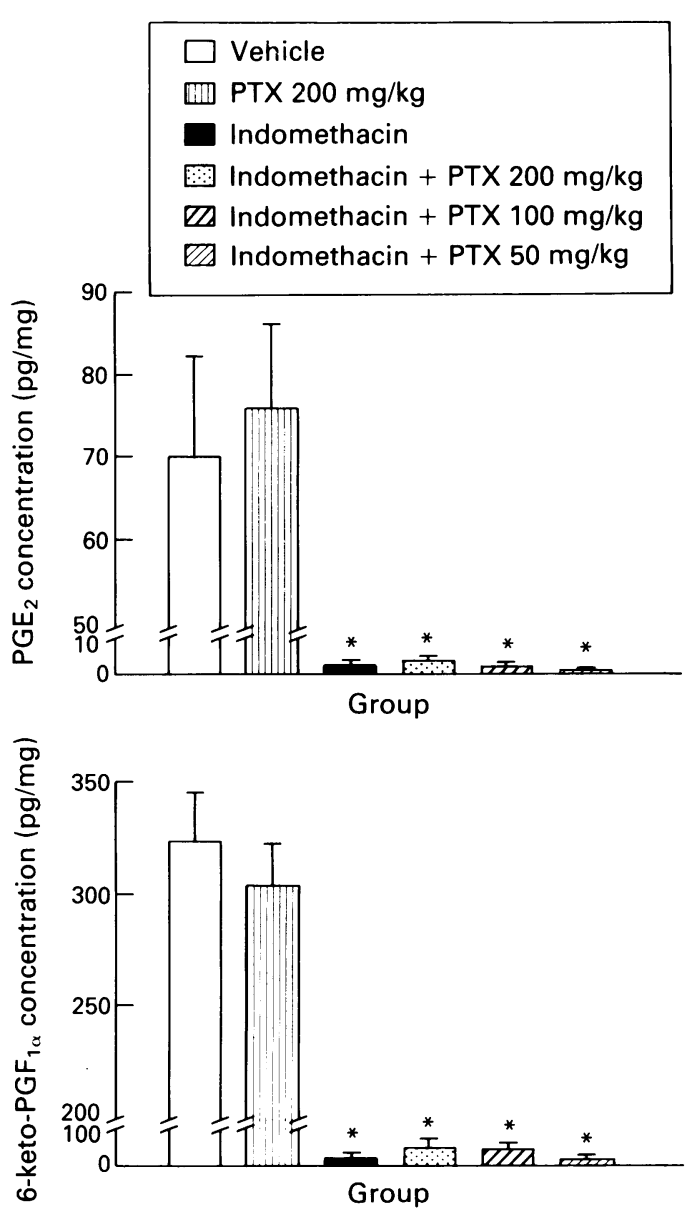

Figure 5: Gastric mucosal concentrations of prostaglandins in untreated rats (vehicle group), in rats treated with 20 $\mathrm{mg} / \mathrm{kg}$ indomethacin alone or in rats pretreated with pentoxifylline (PTX). Each group consisted of five to 10 rats. ${ }^{\star} p<0.01 \mathrm{v}$ vehicle group.

PTX caused a dose dependent reduction in the PMN margination score, and the $\mathrm{ID}_{50}$ was 100 $\mathrm{mg} / \mathrm{kg}$ (Fig 4).

EFFECT OF INDOMETHACIN AND PTX ON GASTRIC MUCOSAL PROSTAGLANDIN CONCENTRATIONS

The mean concentrations of $\mathrm{PGE}_{2}$ and 6-keto$\mathrm{PGF}_{1 \alpha}$ were $70.2(12.5) \mathrm{pg} / \mathrm{mg}$ and 324.0
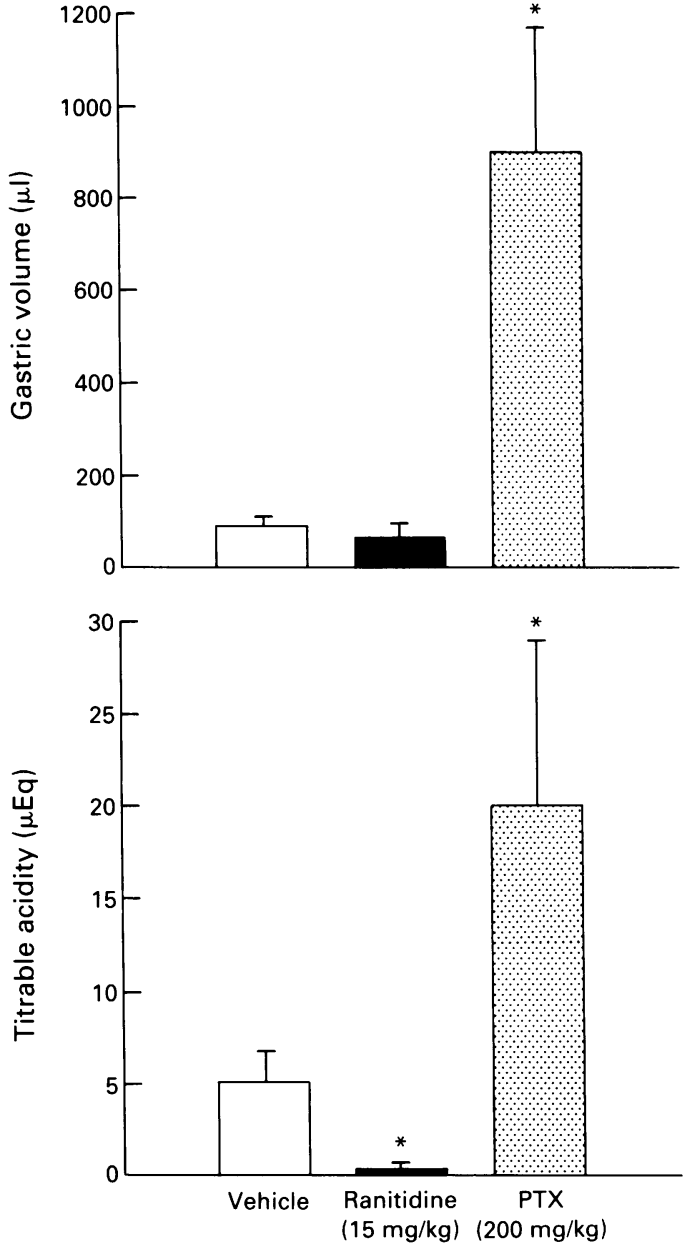

Group

Figure 6: Effect of administration of vehicle, $15 \mathrm{mg} / \mathrm{kg}$ ranitidine, and $200 \mathrm{mg} / \mathrm{kg}$ pentoxifylline (PTX) on basal gastric acid secretion. Rats were pretreated with the reported agents and killed one hour later. Each group consisted of five rats. ${ }^{\star} p<0.05 \mathrm{v}$ vehicle.

$(21 \cdot 2) \mathrm{pg} / \mathrm{mg}$ respectively in control rats and $3 \cdot 3(0 \cdot 1) \mathrm{pg} / \mathrm{mg}$ and $33 \cdot 6(15 \cdot 1) \mathrm{pg} / \mathrm{mg}$ respectively in indomethacin treated animals $(>90 \%$ reduction; $\mathrm{p}<0 \cdot 01)$. PTX administration did not interfere with the reduction of gastric prostanoids induced by indomethacin ( $p>0.05$ $v$ indomethacin alone) (Fig 5).

EFFECT OF PTX ON GASTRIC ACID SECRETION PTX caused a 10 fold increase in gastric volume content, from $90.0(19.6)$ to 900.0 (276.9) $\mu \mathrm{l}(\mathrm{p}<0.05)$ (Fig 6, upper panel), and a fourfold increase in titrable acidity from $5 \cdot 2$ $(1.7)$ to $20.6(9.3)(p<0.05)$ (Fig 6, lower panel). Ranitidine administration reduced the titrable acidity by approximately $90 \%$, but had no effect on the gastric juice volume.

EFFECT OF INDOMETHACIN AND PTX ON SERUM TNF $\alpha$ CONCENTRATIONS

The mean (SEM) TNF $\alpha$ concentrations were $7 \cdot 6(2 \cdot 0) \mathrm{IU} / \mathrm{ml}$ in control rats. Indomethacin significantly increased $\mathrm{TNF} \alpha$ concentrations (Fig 7), while PTX inhibited TNF $\alpha$ release in a dose dependent fashion. When serum TNF $\alpha$ concentrations were plotted against the gastric mucosal damage or PMN margination score, a 
linear correlation was found (Fig 8, upper and lower panel). The $\mathrm{ID}_{50}$ of PTX inhibition on indomethacin induced $\mathrm{TNF} \alpha$ release was approximately $100 \mathrm{mg} / \mathrm{kg}$.

EFFECT OF PRETREATMENT WITH NO INHIBITOR ON PTX INDUCED GASTRIC PROTECTION

Pretreatment with $40 \mathrm{mg} / \mathrm{kg}$ L-NNA increased the indomethacin induced gastric damage from $48.0(8.0) \mathrm{mm}$ to $68.0(10.0) \mathrm{mm}$, but this difference was not significant. Pretreatment with L-NNA did not, however, reverse the protective effect $200 \mathrm{mg} / \mathrm{kg}$ PTX provided against indomethacin induced gastric damage $(48.0(8.0) \mathrm{mm}$ v $6.2(0.5) \mathrm{mm}$, $\mathrm{p}<0 \cdot 05$ ) (Fig 9).

\section{Discussion}

The results of the present study show that PTX prevents the acute gastric damage induced by indomethacin. This drug, a methylxanthine derivative, is a haemorreological agent used for the treatment of peripheral and cerebrovascular diseases. It mainly acts by improving erythrocyte deformability and reducing blood viscosity, platelet aggregation, and plasma fibrinogen concentrations. Recent studies have indicated that PTX has anti-inflammatory properties. It inhibits PMN activation ${ }^{26} 27$ and interleukin 2 (IL-2) mediated PMN adhesion to the vascular endothelium ${ }^{28}$ and reduces the synthesis and release of IL-2, IL-6, and TNF $\alpha$ both in vitro and in vivo. ${ }^{8-10}$

The protective effect of PTX shown in this investigation was dose dependent with an $\mathrm{ID}_{50}$ of approximately $50 \mathrm{mg} / \mathrm{kg}$. PTX was very effective in reducing indomethacin induced

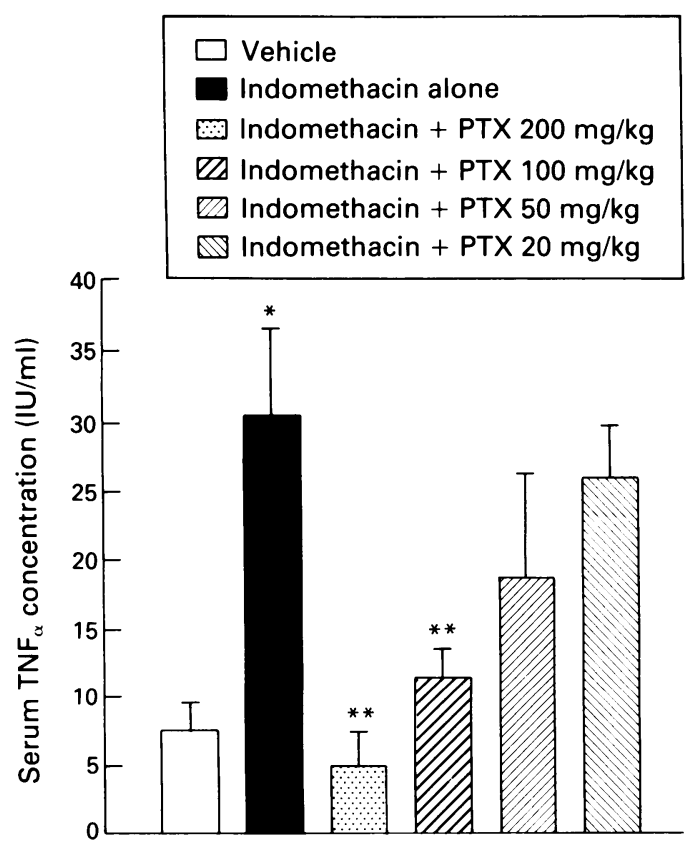

Group

Figure 7: Effect of administration of $20 \mathrm{mg} / \mathrm{kg}$ indomethacin alone or plus $200 \mathrm{mg} / \mathrm{kg}$ pentoxifylline (PTX) on serum tumour necrosis factor $\alpha(T N F \alpha)$ concentrations. Each group consisted of five to 10 rats. ${ }^{\star} p<0.05 \mathrm{v}$ vehicle group; ${ }^{\star \star} p<0.01 \mathrm{v}$ indomethacin alone group. gastric damage and the highest dose tested caused an approximately $90 \%$ reduction in gastric mucosal injury. Several mechanisms could be proposed to account for the protective effect of PTX. Our data indicate that this effect is unrelated to gastric mucosal prostaglandin generation, since pretreatment with doses of PTX which reduced gastric damage by $90 \%$ had no effect on the gastric mucosal prostaglandin concentrations. Furthermore, PTX significantly increased the volume of basal gastric juice and titrable acidity, indicating that its protective effect is not related to the inhibition of gastric acid secretion, as has been shown for other protective agents, such as IL-1 or antisecretive drugs. ${ }^{29}$ The fact that the gastric juice volume was increased approximately 10 fold, while titrable acidity was increased only fourfold, however, suggests that PTX increases the nonoxintic secretion rather than parietal cell secretion. The non-oxintic secretion is a mixture of interstitial fluid (paracellular diffusion) and mucous cell secretion. ${ }^{30}$ Since PTX has previously been shown to increase intestinal microvascular blood flow, ${ }^{31}$ it may be hypothesised that PTX increases paracellular diffusion of interstitial fluid by enhancing

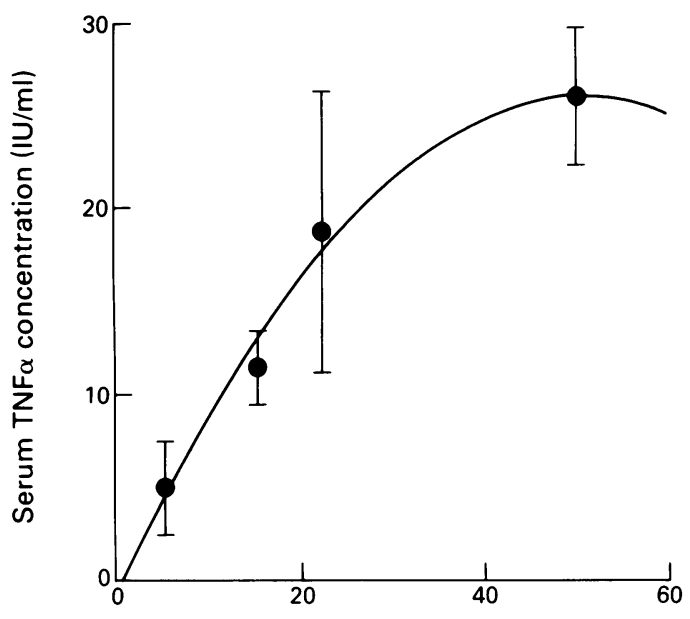

Gastric mucosal damage score $(\mathrm{mm})$

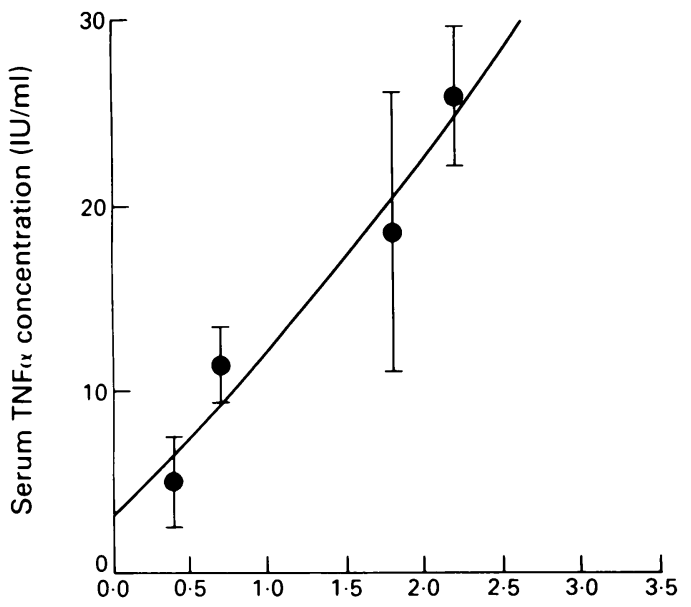

PMN margination score

Figure 8: Correlation between serum tumour necrosis factor $\alpha(T N F \alpha)$ concentrations and gastric mucosal damage score (upper panel) and polymorphonuclear (PMN) margination score (lower panel). 


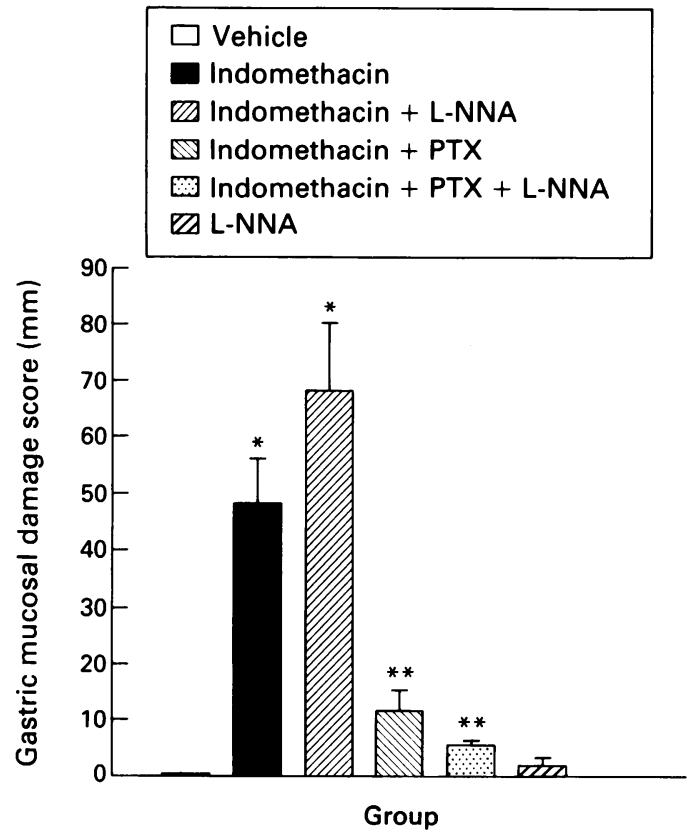

Figure 9: Effect of administration of $40 \mathrm{mg} / \mathrm{kg} \mathrm{N \omega}$-nitro$L$-arginine (L-NNA) on the gastric mucosal damage score induced by intragastric instillation of $20 \mathrm{mg} / \mathrm{kg}$ indomethacin alone or plus $200 \mathrm{mg} / \mathrm{kg}$ pentoxifylline $(P T X)$. Each group consisted of five rats. ${ }^{\star} p<0.05 \mathrm{v}$ vehicle. ${ }^{\star \star} p<0.05 \mathrm{v}$ indomethacin alone or indomethacin plus $L-N N A$.

gastric mucosal blood flow. Since indomethacin reduced the gastric mucosal prostaglandin concentration to the same extent in rats pretreated with PTX or vehicle, it is unlikely that this increment in the gastric volume had any effect on indomethacin pharmacokinetics.

The indomethacin induced PMN margination into the microcirculation of the gastric mucosa documented in our study is consistent with the hypothesis that PMN are important mediators of NSAID induced acute mucosal injury. ${ }^{2-5}$ Kitahora and Guth $^{2}$ reported that the development of vascular stasis and mucosal lesions induced by indomethacin is immediately preceded by the appearance of white thrombi in the gastric microcirculation, and it has been shown that NSAID provoked gastric damage can be prevented by inducing neutropenia with methotrexate or antineutrophil monoclonal antibodies. ${ }^{34}$ As our results shown that PTX administration dose-dependently inhibited PMN infiltration into the gastric mucosa, they offer further confirmation that PMN margination plays an important role in the pathogenesis of indomethacin induced gastric mucosal damage. A similar picture has recently been reported for IL-1, which has been found to reduce the severity of experimental NSAID induced gastric damage by inhibiting the extent of PMN margination. ${ }^{29}$ In addition, as PTX has been shown to reduce elastase and superoxide anion release from PMN in vitro, 2627 it may block the activation and release of toxic substances by PMN marginated into the gastric microcirculation.

PTX could inhibit PMN adherence in a number of ways. PMN adherence is dependent on the appearance of specific surface adhesion proteins on the cell membrane and several agents (for example, leukotriens, IL-1, IL-2, and $\mathrm{TNF} \alpha$ ) are able to induce these adhesion molecules. TNF $\alpha$ is a cytokine that strongly stimulates PMN adherence by inducing the synthesis and expression of the intercellular adhesion molecules ICAM-1 and ELAM-1 on endothelial cells ${ }^{11}$ and LFA-1 and MAC-1 on PMN. ${ }^{32}$ Intravenous administration of TNF $\alpha$ produces extensive PMN margination within the microvasculature of the digestive tract, as well as a spotty necrosis on the surface epithelium of the small bowel and colon. ${ }^{14}$ Furthermore, studies on experimental models of septic shock have shown that TNF $\alpha$ is responsible for the PMN margination and the resulting organ injury. ${ }^{13}$ In vitro studies have documented that indomethacin increases $\mathrm{TNF} \alpha$ synthesis from lypopolysaccharide (LPS) stimulated macrophages, whereas exogenous $\mathrm{PGE}_{2}$ suppresses the release of TNF $\alpha$, as well as the expression of the TNF gene in a dose dependent fashion, ${ }^{17-20}$ indicating that cyclo-oxygenase products may serve as part of the inhibitory feedback loop that limits monocyte-macrophage $\mathrm{TNF} \alpha$ production. It has also been shown that NSAID administration increases TNF $\alpha$ concentrations in both humans and experimental animals. ${ }^{19} 33$ The present results show that PTX administration reduces dose dependently the indomethacin induced $\mathrm{TNF} \alpha$ increase. There was also a linear correlation between serum $\mathrm{TNF} \alpha$ concentrations and both gastric mucosal damage and PMN margination scores, suggesting that prevention of gastric injury and PMN margination by PTX may depend, at least partly, on its ability to modulate $\mathrm{TNF} \alpha$ release.

PTX has been shown to increase gastrointestinal blood flow in animal models of haemorrhagic shock. ${ }^{31}$ In these models, PTX leads to an immediate hyperaemic response, with an increase in microvascular blood flow that protects tissues from the ischaemic damage. This hyperaemic response is mainly dependent on its ability to both increase erythrocyte deformability and reduce blood viscosity, platelet aggregation, and PMN margination. ${ }^{31}$ These haemorreological effects may also contribute to the ability of PTX to prevent indomethacin induced gastric mucosal damage. Although NO has been shown to be a potent vasodilator in the gastrointestinal tract, the fact that L-NNA, a specific inhibitor of NO generation, did not eliminate the protective effect of PTX, suggests that these actions are not mediated by local release of NO. ${ }^{25}$

PTX could also reduce PMN adherence by increasing the local release of factors that inhibit PMN margination. One of these is prostacyclin, ${ }^{34}$ the major prostaglandin produced by the endothelium. This seems unlikely, however, since we showed that PTX reduces PMN margination within the microcirculation without exerting any effect on the mucosal concentrations of $6-$ keto-PGF $_{1 \alpha}$, the stable metabolite of prostacyclin.

In conclusion, PTX prevents indomethacin induced gastric damage in rats. The effect of 
PTX is not related to the synthesis of prostaglandins or to the inhibition of acid secretion, but rather seems, at least partly, to depend on blocking the adherence of PMN to the gastric microcirculation, probably by inhibiting $\mathrm{TNF} \alpha$ synthesis and release.

We thank Judy Dale for reviewing the manuscript and Barbara Federici, Francesca Orsini, and Guido Giglietti for technical assistance.

1 Ivey KJ. Mechanism of NSAID-induced gastric damage: actions of therapeutic agents. Am F Med 1988; 84 (suppl 2A): 41-8.

2 Kitahora T, Guth PH. Effect of aspirin plus hydrochloric acid on the gastric mucosal microcirculation. acid on the gastric mucos

Gastroenterology 1987; 93: 810-7.
3 Wallace JL, Keenan CM, Granger DN. Gastric ulceration induced by nonsteroidal anti-inflammatory drugs is a neutrophil-dependent process. Am f Physiol 1990; 259: G462-7.

4 Lee M, Feldman M. Aspirin-induced acute gastric mucosal injury is a neutrophil-dependent process in rats. $A m \mathcal{F}$ Physiol 1992; 26: G920-6.

5 Wallace JL, Arfors KE, McKnight GW. A monoclonal antibody against the CD18 leukocyte adhesion molecule prevents indomethacin-induced gastric damage in the rabbit. Gastroenterology 1991; 100: 878-83.

6 Vedder NB, Winn RK, Rice CL, Chi EY, Arfors KE, Harlan JM. A monoclonal antibody to the adherencepromoting leukocyte glycoprotein, CD18, reduces organ promoting leukocyte glycoprotein, CD18, reduces organ injury and improves survival from hemorrhagic shock and
resuscitation in rabbits. $\mathcal{F}$ Clin Invest 1988; 81: 939-44.

resuscitation in rabbits. F Clin Invest 1988; 81: 939-44.
7 Yonemaru $M$, Hatherill JR, Hoffmann $\mathrm{H}$, Zheng $\mathrm{H}$, Ishii K, Raffin TA. Pentoxifylline does not attenuate acute lung injury in the absence of granulocytes. $\mathcal{F}$ Appl Physiol 1991; 71: $342-51$.

8 Doherty GM, Jensen JC, Alexander HR, Buresh CM, Norton JA. Pentoxifylline suppression of tumor necrosis factor gene transcription. Surgery 1991; 110: 192-8.

9 LeMay LG, Vander AJ, Kluger MJ. The effects of pentoxifylline on lipopolysaccharide (LPS) fever, plasma interfylline on lipopolysaccharide (LPS) fever, plasma inter-
leukin 6 (IL6), and tumor necrosis factor (TNF) in the leukin 6 (IL6), and tumor necro
rat. Cytokine 1990; 2: 300-6.

10 Zabel P, Schonharting MM, Shade UF, Schlaak JM. Effect of pentoxifylline in endotoxinemia in human volunteers. Prog Clin Biol Res 1991; 367: 207-13.

11 Pohlman TH, Stannes KA, Beatty PG, Ochs HD, Harlan JM. An endothelial cell surface factor(s) induced in vitro by lipopolysaccharide, interleukin 1 and tumor necrosis factor- $\alpha$ increases neutrophil adherence by CDw18dependent mechanism. F Immunol 1986; 136: 4548-53.

12 Birdsall $\mathrm{HH}$. Induction of ICAM-1 on human neural cells and mechanisms of neutrophil-mediated injury. $\mathrm{Am} \mathcal{F}$ Pathol 1991; 139: 1341-50.

13 Tracey KJ, Beutler B, Lowrey SL, Merryweather J, Wolpe $S$, Milsark IW, et al. Shock and tissue injury induced by recombinant human cachectin. Science 1986; 234: 470-5.

14 Remick DG, Kunkel RG, Larrick JW, Kunkel SL. Acute in vivo effects of human recombinant tumor necrosis factor. Lab Invest 1987; 56: 583-90.

15 Sayers TG, Wiltrout TA, Bull CA, Denn III AC, Pilaro AM, Lokesh B. Effect of cytokines on polymorphonuclear neutrophil infiltration in the mouse. $\mathcal{F}$ Immunol 1988; 141: 1670-7.

16 Kettelhut IC, Fiers W, Goldberg LA. The toxic effects of tumor necrosis factor in vivo and their prevention by cyclooxygenase inhibitors. Proc Natl Acad Sci USA 1987; 84: 4273-7.
17 Fieren MW, Van den Bemd GJ. Ben-Efraim S, Bonta IL. Prostaglandin E2 inhibits the release of tumor necrosis factor-alpha, rather than interleukin 1 beta, from human macrophages. Immunol Lett 1992; 31: 85-90.

18 Marcinkiewicz J. In vitro cytokine release by activated murine peritoneal macrophages: role of prostaglandins in murine peritoneal macrophages: role of prostaglandins in interleukin 1, and interleukin 6. Cytokine 1991; 3: 327-32.

19 Spatafora M, Chiappara G, D'Amico D, Volpes D, Melis $M$, Pace E, Merendino A. Effect of indomethacin on the kinetics of tumor necrosis factor alpha release and tumor necrosis factor alpha gene expression by human blood monocytes. Pharmacol Res 1991; 23: 247-57.

20 Ferreri NR, Sarr T, Askenase PW, Ruddle NH. Molecular regulation of tumor necrosis factor-alpha and lymphotoxin production in $\mathrm{T}$ cells. Inhibition by prostaglandin $\mathrm{E}_{\text {. }}$ f Biol Chem 1992; 267: 9443-9.

21 Redfern JS, Lee E, Feldman M. Effect of indomethacin on gastric mucosal prostaglandins in human. Correlation gastric mucosal prostaglandins in human. Correlation

22 Ferman N, Pradelles P, Bonvaelt JP. PGE 2 , PGF, , 6-keto$\mathrm{PGF}_{1 \mathrm{a}}$ and $\mathrm{TXB}_{2}$ synthesis along the rabbit nephron. $\mathrm{Am}$ f Physiol 1987; 252: F53-9.

23 Pradelles P, Grassi J, Maclouf J. Enzyme immunoassays of eicosanoids using acetylcholine esterase as label: an alternative to radioimmunoassay. Anal Chem 1985; 57: 1170-3.

24 Lau AS, Livesey JS. Endotoxin induction of tumor necrosis factor is enhanced by acid-labile interferon-alpha in acquired immunodeficiency syndrome. F Clin Invest 1989; 84: 738-43.

25 Whittle BJR, Lopez-Belmonte J, Moncada S. Regulation of gastric mucosal integrity by endogenous nitric oxide: interactions with prostanoids and sensory neuropeptides in rat. Br $\mathcal{F}$ Pharmacol 1990, 99: 607-11.

26 Oka Y, Murata A, Nishijima J, Hiraoka N, Yasuda T, Kitagawa $\mathrm{K}$, et al. Inhibitory effect of pentoxifylline and prostaglandin E1 on the release of neutrophil elastase from FMLP-stimulated neutrophils. $\mathcal{F}$ Med Clin Exp Theor 1991; 22: 371-82.

27 Thiel M, Bordenheuer H, Poch G, Madel C, Peter K. Pentoxifylline does not act via adenosine receptors in the inhibition of the superoxide anion production of human polymorphonuclear leukocyte. Biochem Biophys Res Commun 1991; 180: 53-8.

28 Edwards MJ, Abney DL, Miller FN. Pentoxifylline inhibits interleukin-2-induced leukocyte-endothelial adherence
and reduces systemic toxicity. Surgery 1991; 110: and reduces

29 Wallace JL, Keenan CM, Cucala M, Mugridge KG, Parente L. Mechanisms underlying the protective effects of interleukin 1 in experimental nonsteroidal anti-inflammatory drug gastropathy. Gastroenterology 1992; 102: 1176-85.

30 Daugherty DF, Lucey MR, Yamada T. Gastric secretion. In: Yamada $\mathrm{T}$, ed. Textbook of gastroenterology. Philadelphia: JB Lippincott Co, 1991: 233-64.

31 Flynn WJ, Cryer HG, Garrison RN. Pentoxifylline restores intestinal microvascular blood flow during resuscitated hemorrhagic shock. Surgery 1991; 110: 350-6.

32 Dustin ML, Springer TA. T-cell receptor cross-linking transiently stimulates adhesiveness through LFA-1. transiently stimulates adhes

33 Martich GD, Parker MM, Cunnion RE, Suffredini AF. Effect of ibuprofen and pentoxifylline on the cardiovascular response of normal humans to endotoxin. $\mathcal{F} A p p l$ Physiol 1992; 73: 925-31.

34 Fantone JC. Mechanism of chemotactic factor stimulation of polymorphonuclear leukocyte: modulation by prostaglandins. In: Higgs GA, Williams TJ, eds. Inflammatory mediators. London: MacMillan, 1985: 127-48. 